\title{
Experimental Examination of Scalable Under Water Launching Missile System
}

\author{
J. Sarathkumar Sebastin, S. Jeyakumar
}

\begin{abstract}
Experimental Investigations were carried out to study the performance of underwater launching missile system by adapting the electromagnetic launcher concept. There are two energy sources utilized to propel the missile in this proposed research; solid propellant motor and electromagnetic launcher. Electromagnetic launcher propels the missile from underwater to the water surface. Solid propellant motor propels the missile from water surface to the fixed target in the atmosphere. Solid propellants were prepared and the specific impulse of the propellants was also observed by impulse measuring system. 65/35 ratio of fuel-oxidizer (KNO3-Succrose) has the specific impulse of 89.3 seconds. Rope test and vertical launch test were conducted for finding out the missile altitude and performance as well. The Electromagnetic launcher used in this research can replace torpedo tubes which are conventionally fitted with compressor supply. Since capacitor banks are being used as power source for the launcher, reusability and simplicity of the launching system are improved remarkably. The electromagnetic launcher generates Lorentz force to accelerate the missile through the water. 220VDC, 5000 $\mu F D$ capacitors connected in parallel produce $363 \mathrm{~N}-\mathrm{m}$ energy. 10grams of missile model made up of aluminium material was tested and found velocity and projectile of the missile.
\end{abstract}

Keywords: Solid Propellant, Electro Magnetic launcher, Specific Impulse, Capacitor, Fuel-oxidizer.

\section{INTRODUCTION}

The Basic principle of Submarine Launched Ballistic Missile (SLBM) is its two stage process during missile launch. The missile engine does not actually start until it is clear out of the water. SLBM actually gets pushed out by high pressure air with enough force to lift the missile a few feet out of the water, and then the missile engine is started. The inactivated missile gets pushed out by Electromagnetic force to lift the missile a few meters out of the water, and then the missile engine is started by its own chemical energy. The specific objectives of the study are, (i) to create the electromagnetic force using capacitor bank and analyse the effect of Lorentz force, (ii) to enhance the propulsive efficiency of the launcher, and (iii) too make the launching process more reliable and flexible. In addition, the solid propellant chemical rocket model is made and experiment

Revised Manuscript Received on December 5, 2019

* Correspondence Author

*J. Sarathkumar Sebastin, Aeronautical Engineering, Kalasalingam Academy of Research and Education, Tamil Nadu-626126, India. Email: sebastinaero@gmail.com

S. Jeyakumar, Aeronautical Engineering, Kalasalingam Academy of Research and Education, Tamil Nadu-626126, India. Email: sjeyakumar1974@gmail.com is conducted to evaluate the overall performance of the projectile. Evaluate the specific impulse of the propellant. To combine the electronic ignition unit and experiment real time underwater launching test. Jeff Maniglia et.al. [1], made a rail gun, and explained the Lorentz force experimentally. A rail gun consists of a power supply that drives current through a pair of conductors or rails to accelerate a projectile to high velocity.

$$
\mathrm{F}=\mathrm{B} * \mathrm{I} * \mathrm{~L}
$$

Where, F-Force; B-magnetic flex; I-current; L- Rail's length. A high voltage power supply is required to charge the capacitor banks. In this case, a square wave inverter along with a full wave rectifier is used for the purpose. A simple closed-loop control system is equipped for charge control for the capacitor banks. The feedback from capacitor is provided with simple potential divider mechanism with suitable resistances as a potential divider. A rail gun operates on the principles of electrodynamics and utilizes a large Lorentz force to accelerate a nonexclusive projectile from between two rails to supersonic speeds. This Lorentz force is created by a loop of current that runs up one rail, through the conductive projectile itself, and then down the other rail. The current running up and down either rail produces a magnetic field between the rails that interacts with the current running through the projectile itself to produce the Lorentz force that accelerates the projectile.

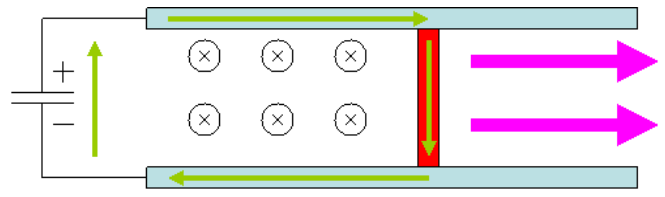

Fig.1. Rail gun launcher schematic view

Rail-projectile does not require a long duration of power supply. The charged capacitor bank is being used because of its instantaneous high current and high voltage supply.

Rail - Armature design

Aluminium is used as choice for armature and copper is

used as choice for rails, because of their incredible conductivity and ease of machining and low cost. To reduce wear and tear in rails, which is permanent part of the launching system, copper is selected over aluminium and as the projectile body being a continuously replaced component in the system aluminium is chosen in aspect of cost and life. 
The armature is given a U-shaped tail structure to establish continuous physical contact and to prevent sporadic arcing of electrically charged body. The prototype of electromagnetic launcher consists of a muzzle door made of aluminium foil to simulate a water prevention lid, which the missile in real time must breakthrough to escape from the torpedo tube.

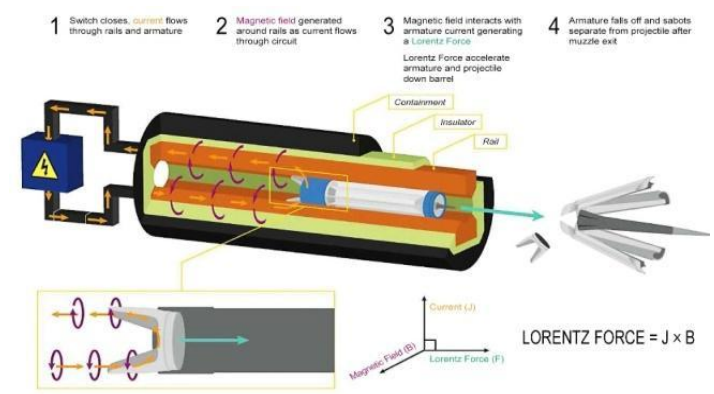

Fig 2. Rail Armature design schematic view

A muzzle door (aluminium foil) is fitted at the top of the electromagnetic launcher, used to provide initial momentum to the armature, and acts as an isolating material, to prevent outside water to the launcher [10,16]. The armature outer casing is designed in such a way that the armature base will be in contact with both the rails. (This material fitting is referred as "Transient fit").

\section{MATERIALS \& METHODOLOGY}

\section{Solid Propellant Preparation}

The solid propellant system is involved in the propellant making, propellant property test (specific impulse), propellant ignition, rope test, and the ground test of the propellant (vertical launch). We have made a solid propellant of Potassium Nitrate $\left(\mathrm{KNO}_{3}\right.$ oxidizer $)$ - Sugar $\left(\mathrm{C}_{12} \mathrm{H}_{22} \mathrm{O}_{11}\right.$ fuel $)$. Propellants impart motion to an object through the conversion of potential energy into useful kinetic energy. There are four types of solid propellant preparation techniques. There are Dry ramming, Melting/Casting, Moist pressing and Recrystallization. Recrystallization method is used in this proposed research for safe and easy operation. The following propellant combinations were made for the propellant property test.

Test 1: $\mathrm{KNO}_{3}+\mathrm{C}_{12} \mathrm{H}_{22} \mathrm{O}_{11}(65: 35$ Ratio $)$

Test 2: $\mathrm{KNO}_{3}+\mathrm{C}_{12} \mathrm{H}_{22} \mathrm{O}_{11}+\mathrm{Al}$ powder

Test 3: $\mathrm{KNO}_{3}+\mathrm{C}_{12} \mathrm{H}_{22} \mathrm{O}_{11}$ (ratio 60/40)

Test 4: $\mathrm{KNO}_{3}+\mathrm{C}_{12} \mathrm{H}_{22} \mathrm{O}_{11}+$ Aluminium powder+ Sulphur

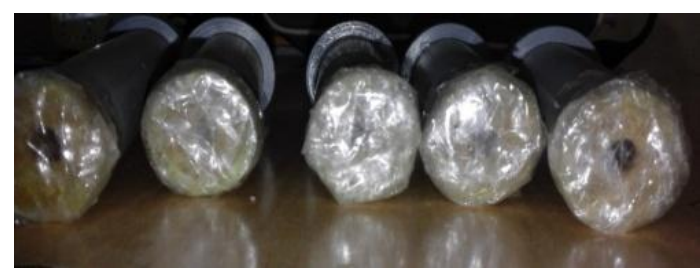

Fig.3. Stored propellant charge

The grain size of the ingredients used is microscopic. The paste form of the propellant charge is stored in the propellant motor (PVC material casing) as shown in Figure 3. To avoid oxidation, it is isolated from the air. In this study electric match (pyrotechnique) is used for the ignition. An electric match is a device that uses an externally applied electric current to ignite a combustible compound.

A simple total impulse measuring technique was adapted to find out the propellant properties. The following tools were used in the total impulse measuring unit: Thermocouple with digital indicator and Load cell $(0-2 \mathrm{Kg})$. A sensitive weighing machine (Load cell) calibrated the force in terms of grams, proportional to the thrust force as shown in Figure4.

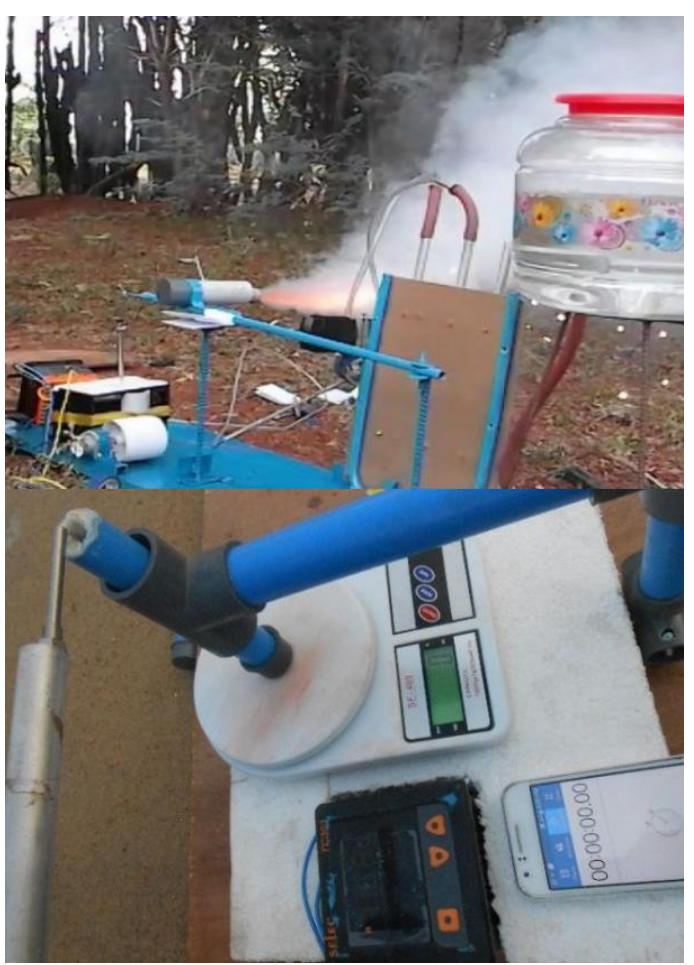

Fig.4. Proposed experimental setup of total impulse measuring unit (Horizontal)

\section{Propellant Property Test:}

The small scaled propellant motor with the following dimensions were tested. Solid motor length $12 \mathrm{~cm}$; Solid motor, Diameter $2.5 \mathrm{~cm}$; Exit Nozzle Diameter $0.3 \mathrm{~cm}$; Empty Motor weight 20grams. The test specimen was fixed in the impulse measuring unit as shown in

figure 4.b. When it was fired with the help of electric match, it produced thrust which is measured in terms of gram force with the load cell $(0-2 \mathrm{Kg})$. The following Table 1 shows the readings taken in all 4 tests.

The following equations are used to find the best suited propellant for the further experimental studies.

- Total Impulse $=($ Thrust $*$ Burning time $)$

- Specific Impulse $=($ Total Impulse/ Total burning propellant weight)

- Mass flow rate $=$ Propellant mass $/$ Rocket Operation Duration)

- Thrust $=\left(\right.$ Specific impulse ${ }^{*}$ Gravity*mass flow rate $)$

- Effective Exhaust velocity = (specific impulse* Gravity)

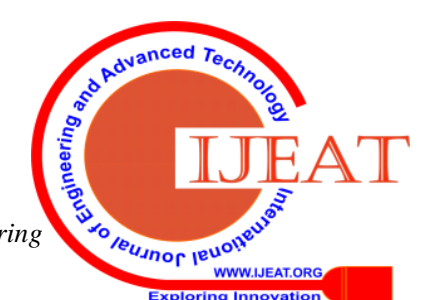


Table No: 1. Thrust load for Solid propellant combinations

\begin{tabular}{|c|c|c|c|c|c|}
\hline $\begin{array}{l}\text { Test } \\
\text { No. }\end{array}$ & $\begin{array}{c}\text { Propellant } \\
\text { combinations }\end{array}$ & $\begin{array}{c}\text { Propellant } \\
\text { weight } \\
\text { (in gram s) }\end{array}$ & $\begin{array}{c}\text { Effective } \\
\text { Burning } \\
\text { time (in } \\
\text { sec) }\end{array}$ & $\begin{array}{c}\text { Tempera } \\
\text { ture } \\
\text { reading } \\
(\text { deg. C) }\end{array}$ & $\begin{array}{l}\text { Thrust } \\
\text { load (in } \\
\text { Newton) }\end{array}$ \\
\hline 1 & $\begin{array}{c}\text { KNO3+ } \\
\text { C12H22O11 } \\
\text { (65/35 ratio) }\end{array}$ & 90 & 4 & 530 & 7.6518 \\
\hline 2 & $\begin{array}{c}\mathrm{KNO}_{3} \\
+\mathrm{C}_{12} \mathrm{H}_{22} \mathrm{O}_{11} \\
+ \text { Aluminium } \\
\text { powder }\end{array}$ & 100 & 5 & 610 & 7.5537 \\
\hline 3 & $\begin{array}{c}\mathrm{KNO}_{3}+ \\
\mathrm{C}_{12} \mathrm{H}_{22} \mathrm{O}_{11} \\
(60 / 40 \text { ratio })\end{array}$ & 90 & 4 & 470 & $\begin{array}{c}7.3084 \\
5\end{array}$ \\
\hline 4 & $\begin{array}{c}\mathrm{KNO}_{3} \\
+\mathrm{C}_{12} \mathrm{H}_{22} \mathrm{O}_{11} \\
+ \text { Aluminium } \\
\text { powder+ } \\
\text { sulphur }\end{array}$ & 105 & 5 & 618 & 7.0632 \\
\hline
\end{tabular}

The calculations of specific impulse and other related terms are tabulated in Table 2.

Table: 2. Propellant specific impulse readings

\begin{tabular}{|c|c|c|c|c|c|c|}
\hline $\begin{array}{c}\text { Test } \\
\text { No. }\end{array}$ & $\begin{array}{c}\text { Burnout } \\
\text { time } \\
(\mathrm{sec})\end{array}$ & $\begin{array}{c}\text { Force } \\
\text { (in } \\
\text { New } \\
\text { ton })\end{array}$ & $\begin{array}{c}\text { Total } \\
\text { impulse } \\
(\mathrm{N}-\mathrm{sec})\end{array}$ & $\begin{array}{c}\text { Specific } \\
\text { Impulse } \\
(\mathrm{sec})\end{array}$ & $\begin{array}{c}\text { Mass } \\
\text { flow rate } \\
(\mathrm{Kg} / \\
\mathrm{sec})\end{array}$ & $\begin{array}{c}\text { Effective } \\
\text { exhaust } \\
\text { velocity } \\
(\mathrm{m} / \mathrm{sec})\end{array}$ \\
\hline 1. & 4 & 7.6518 & 30.6072 & 34.6667 & 0.0225 & 340.080 \\
\hline 2 & 5 & 7.5537 & 37.7685 & 38.500 & 0.020 & 377.685 \\
\hline 3 & 4 & 7.3084 & 29.2336 & 33.1108 & 0.0225 & 324.816 \\
\hline 4 & 5 & 7.0632 & 35.316 & 34.2857 & 0.021 & 336.3427 \\
\hline
\end{tabular}

After conducting the propellant property test, the efficient propellant combination is found as test 2 propellant $\left(\mathrm{KNO}_{3}\right.$ $+\mathrm{C}_{12} \mathrm{H}_{22} \mathrm{O}_{11}+$ Aluminum powder) with the specific impulse of 38.5 seconds. So that the above mentioned test 2 propellant combination was used throughout the proposed work as chemical propellant energy resource.

Electromagnetic launcher - Ground test:

The high current and high voltage from the capacitor bank helps to generate Lorentz force perpendicular to the current direction which forces the missile to come over the water surface. The following Figure 5 and 6 represent the theoretical and practical model of the rail gun launcher respectively. The Lorentz force is created because of the current flow through the armature which interacts with the magnetic field produced by the parallel gun rails. A charger unit is used to charge the capacitor bank. The initial mass driver (small compressor) with 2 bar is connected to the rail gun model to provide initial momentum and to avoid self-weld fusion of the projectile with the rails. The capacitor bank was separated from the charging unit and connected to the rail gun launcher.

The capacitor bank charger, shown in Fig.6a, consists of a bridge rectifier (E2510) of 25A, wire wound resistor $(50 \mathrm{~W}$, $250 \mathrm{E}$ ), voltage transformer (power factor of $1 \mathrm{KVA}$ ). A $230 \mathrm{~V}$ AC supply is provided to the charger board which could be altered by the voltage regulator. The current was passed through two serially connected voltage regulators $\left(\mathrm{V}_{1}, \mathrm{~V}_{2}\right)$ of $2000 \mathrm{~W}$ range, and then it passed through the bridge rectifier E2510 which converts the AC voltage into DC voltage. An aluminium heat sink is provided with the bridge rectifier. The DC supply was passed through the parallel wire wound resistors $\left(R_{\text {equ }}=15 \mathrm{~K}-\Omega\right)$ and the output $\mathrm{DC}$ supply was brought to the capacitor bank.

The Projectile launcher consists of two parallel rails of $450 \mathrm{~mm}$ length separated by a distance of $10 \mathrm{~mm}$; the rails made of copper bar of $12 \mathrm{~mm}$ diameter were used as shown in Fig.6b. The rails which are of copper are laid parallel to each other at distance. These are fixed on the insulator bars. Then the wires are connected on both rods and these wires are connected to the capacitor bank. The instant large charge released by the capacitor bank helped to move the projectile at a high velocity. The initial push was given with the help of a compressor.

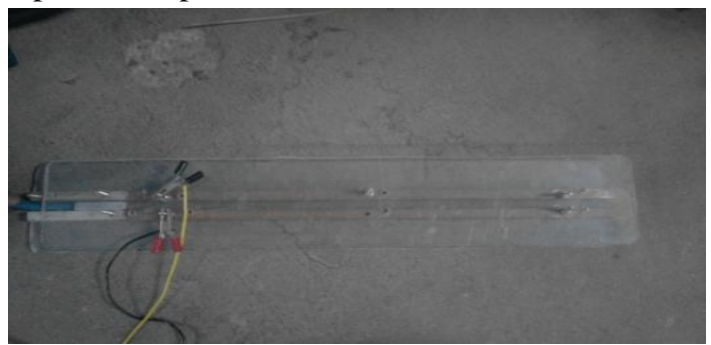

Fig.5. Rail -Projectile Setup

Aluminium is used as choice for armature and copper is used as choice for rails, because of their incredible conductivity and ease of machining and low cost. To reduce wear and tear in rails, which is permanent part of the launching system copper is selected over aluminium and as the projectile body being a continuously replaced component in the system aluminium is selected in aspect of cost and life. In the scaled capacitor bank, three capacitors were connected in parallel, which had a capacitance of $5000 \mu \mathrm{FD}, 220 \mathrm{~V}$ DC.

The electrical energy stored in the capacitor is potential energy. Capacitor's potential energy is equal to the projectile's kinetic energy.

K.E. $=0.5^{*} \mathrm{~m}^{*} \mathrm{v}^{2}$

Projectile specimen mass $m=10 \mathrm{~g}$ (from the small scaled ground test, as shown in Fig.6.b). The stored energy in the capacitor bank is $\mathrm{E}=\left(0.5 * \mathrm{C} * \mathrm{~V}^{2}\right)$ Three capacitors were connected in parallel with the capacitance of $5000 \mu \mathrm{FD}$.

Equivalent capacitance, $\mathrm{C}_{\mathrm{equ}}=\left(\mathrm{C}_{1}+\mathrm{C}_{2}+\ldots\right)$

Cequ $=0.015 \mathrm{~F}$
$\mathrm{E}=0.5 * 0.015 * 220^{2}$
$\mathrm{E}=363 \mathrm{~N}-\mathrm{m}$
Charge $\mathrm{Q}=\mathrm{C} * \mathrm{~V}$
$\mathrm{Q}=0.015 * 220$
$\mathrm{Q}=79.86^{*} 10^{3}$ coulombs




\section{Experimental Examination of Scalable Under Water Launching Missile System}
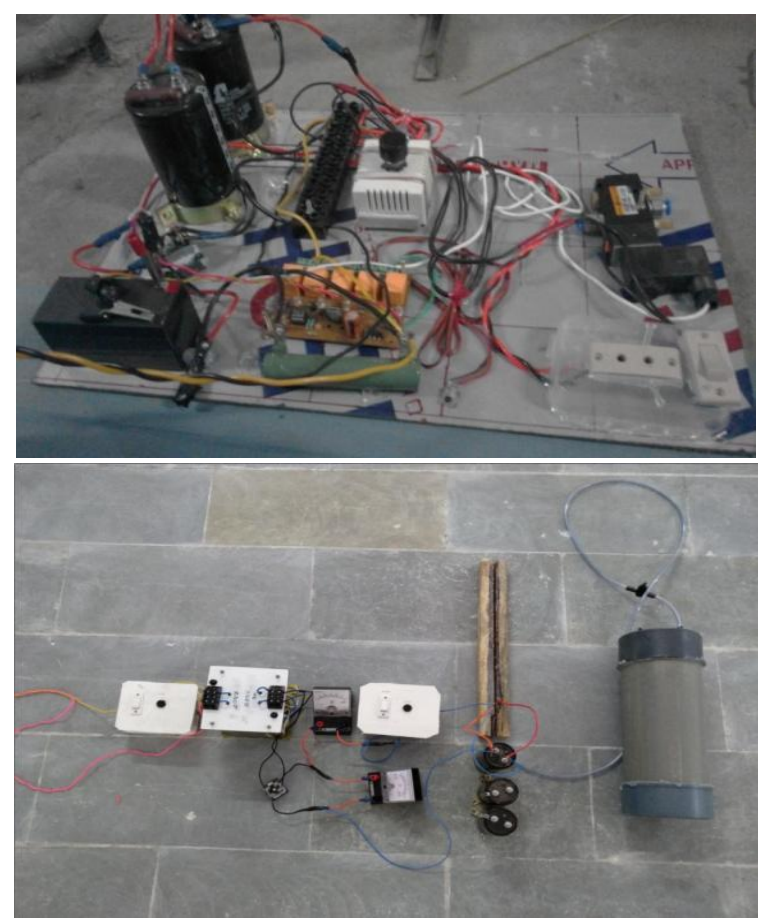

Fig.6a, 6b. Practical model of Rail gun launcher setup

Capacitor bank charger was used to charge the capacitors up to a voltage of $220 \mathrm{~V} \mathrm{DC}$, and then the charger circuit was replaced with the rails (as shown in Fig.7.).

Once the compressor was started, a Lorentz force was generated. This Lorentz force provided the required acceleration to the armature. The projectile velocity was calculated by high speed camera. We placed a high precision camera above the launcher. The following calculation explains the way of calculating the projectile velocity by means of image processing.
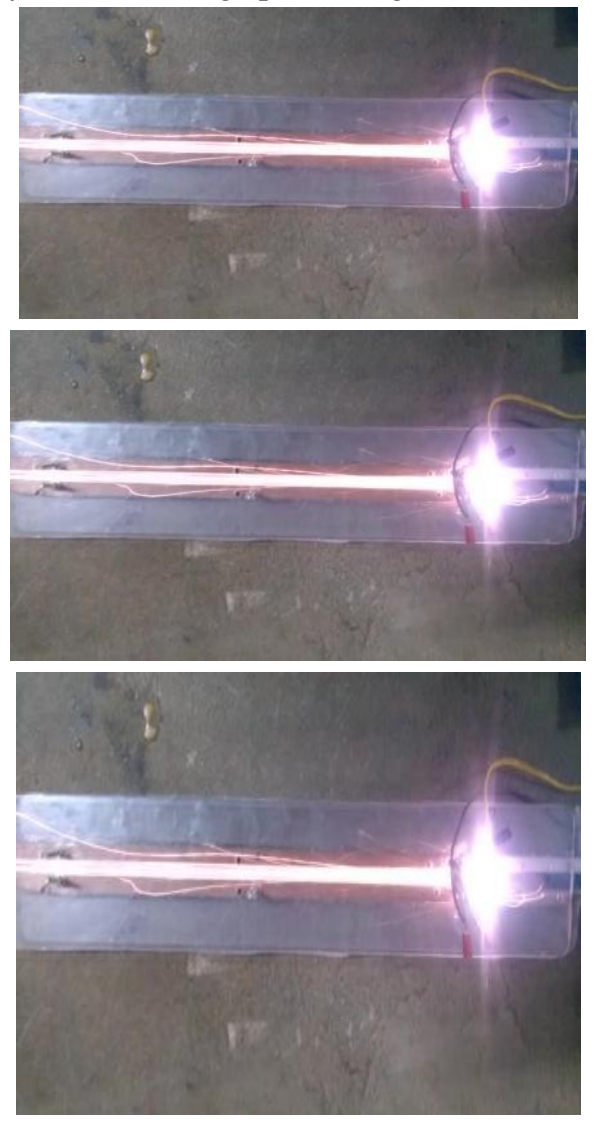
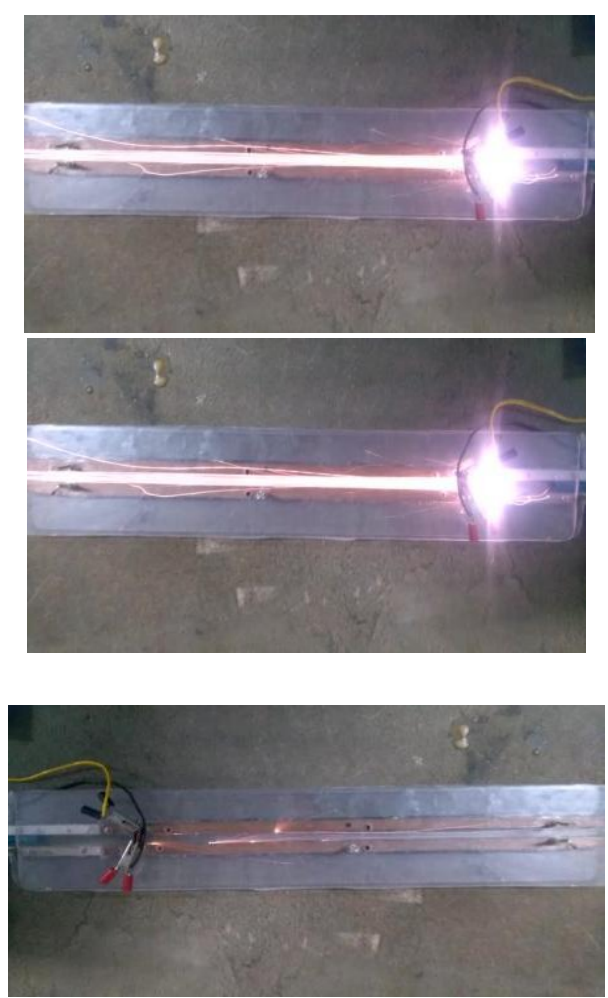

Fig.7. Projectile velocity -

Image processing technique

Table: 3. Experimental data for the projectile image processing velocity readings

\begin{tabular}{|l|c|c|c|c|}
\hline $\begin{array}{c}\text { Power } \\
\text { source } \\
\text { Charge } \\
\text { voltage })\end{array}$ & $\begin{array}{c}\text { Video } \\
\text { frame per } \\
\text { second }\end{array}$ & $\begin{array}{c}\text { No. of } \\
\text { frames (from } \\
\text { the projectile } \\
\text { motion start } \\
\text { to end in the } \\
\text { launcher) }\end{array}$ & $\begin{array}{c}\text { Pelocity } \\
\text { Projectile } \\
\text { Vels }\end{array}$ & Projectile \\
Thrust (N) & \\
\hline $\begin{array}{l}\text { compress } \\
\text { or (2 bar) }\end{array}$ & 125 & 60 & 0.9375 & 0.0195 \\
\hline 50 V DC & 250 & 48 & 2.34375 & 0.122 \\
\hline 100V DC & 166.667 & 6 & 12.5 & 3.47 \\
\hline 150V DC & 166.667 & 5 & 15 & 5 \\
\hline 220V DC & 166.667 & 4 & 18.75 & 7.8125 \\
\hline
\end{tabular}

The projectile was pushed by the Lorentz force of $7.8125 \mathrm{~N}$ and the velocity of $18.75 \mathrm{~m} / \mathrm{s}$ at the given power of 220VDC. It is sufficient to launch the missile from the underwater to the water surface. For a single capacitor powered launcher (@200VDC), Output is $1.7578 \mathrm{~N}-\mathrm{m}$, Input is $100 \mathrm{~N}-\mathrm{m}$. The efficiency of the electromagnetic launcher system is $1.7578 \%(\sim 2 \%)$. 


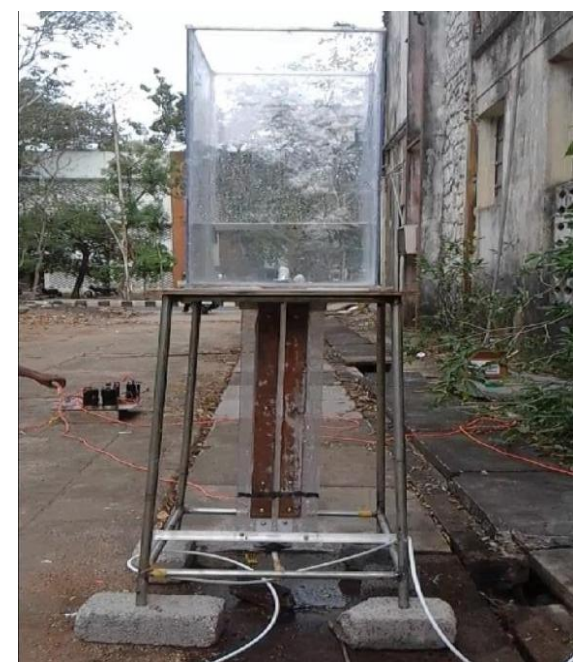

Fig.8. Underwater Environment test setup

The prototype of electromagnetic launcher consists of a muzzle door made of aluminium foil to simulate a water prevention lid, which the missile in real time must breakthrough to escape from the torpedo tube.

As referred in the Fig.8, the electromagnetic launcher outer casing acts as the insulating medium separates water environment and electromagnetic unit. The long rails (made of copper materials) of length $(\mathrm{L}=30 \mathrm{~cm})$ is placed with the separation distance of $8.2 \mathrm{~cm}$ (armature outer casing diameter). Both the rails are connected with the capacitor bank unit. A muzzle door (aluminium foil) is fitted at the top of the electromagnetic launcher, used to provide initial momentum to the armature and acts as an isolating material, to prevent outside water to the launcher.

The armature outer casing is designed in such a way that the armature base will be in contact with both the rails. (This material fitting is referred as, "Transient fit"). Once the capacitor bank is energized then the initial mass driver starts pushing the armature with an initial velocity to avoid armature-rails welding.

As per the Lorentz force equations, the armature velocity can be calculated. A high speed camera can be fitted near the electromagnetic launcher to observe the moment of armature; So that we can find the armature velocity.

Four different propellant combinations were tested for finding out the thrust and specific impulse of the propellant combinations in which the test $2\left(\mathrm{KNO}_{3}+\mathrm{C}_{12} \mathrm{H}_{22} \mathrm{O}_{11}+\right.$ Aluminum powder combination) has more $\mathrm{I}_{\mathrm{sp}}$ value than that of others ( $\mathrm{I}_{\mathrm{sp}}=38.5$ seconds). In test $2\left(\mathrm{KNO}_{3}+\mathrm{C}_{12} \mathrm{H}_{22} \mathrm{O}_{11}+\right.$ Aluminum powder combination) the burning time, total impulse, and effective exhaust velocity was more as compared with other propellants. In addition, it is concluded that, the properties of adding aluminum with the fuel oxidizer combination provided more nozzle exit temperature. The test 2 propellant was chosen for the further experimental studies because of its better performance. The proposed impulse measuring system was the simple tool helped us to find the

\section{RESULTS AND DISCUSSIONS}

propellant properties and its performance in the easiest and efficient wayat $x / L c=0.29$ ) of the rectangular cavity is owed to separated shear layer characteristics inherited in the flow that promotes stronger shock waves, leading to compressive zone.

\section{Projectile Velocity and the launcher efficiency} experiment - Ground test

A small scaled rail gun setup was fabricated and a model projectile was tested for the making of Lorentz force. A prototype consisting of $45 \mathrm{~cm}$ long rail gun was fabricated and tested. The recorded firings accelerated armature of mass 10 grams to a velocity of $18.75 \mathrm{~m} / \mathrm{sec}$ at the supplied power of $220 \mathrm{~V}$ DC Volt. By varying the supply voltage $(50 \mathrm{~V}$ dc to $220 \mathrm{~V}$ DC) from capacitor bank, Missile velocity was varied as per the Lorentz force equation.

From the plot it is shown that high current and high voltage capacitor bank power supply can produce the sufficient projectile velocity to accelerate the missile to come out of the water surface. Similarly, the required Lorentz force could be achieved only by giving the high voltage power supply to the system. The recorded firings accelerated armature of mass 10 grams to a velocity of $18.75 \mathrm{~m} / \mathrm{sec}$ at the supplied power of 220 DC Volt. Since the Lorentz force $(7.8125 \mathrm{~N})$ is enough to propel the armature out of the water surface; electromagnetic launcher can be the right alternative mass driver for the underwater launching missile technology.

The projectile was pushed by the Lorentz force of $7.8125 \mathrm{~N}$ and the velocity of $18.75 \mathrm{~m} / \mathrm{s}$ at

the given power of $200 \mathrm{~V}$ DC. It is sufficient to launch the missile from the underwater to the water surface. It is observed that for a single capacitor powered launcher (@ $220 \mathrm{VDC}$ ) the output is $1.7578 \mathrm{~N}-\mathrm{m}$ and Input is $100 \mathrm{~N}-\mathrm{m}$. The efficiency of the electromagnetic launcher system is $1.7578 \%$ ( 2\%). For the capacitor bank of 20 capacitors connected in parallel produces $89.4427 \mathrm{~m} / \mathrm{s}$ projectile velocity which is enough to come out of the water surface. Hence, the projectile can be chemically powered once it reaches the water surface. Meanwhile, to industrialize this proposed research work, the cost, Safety, Maintainability, and other factors are highly considered. By the use of Electrical systems as primary mass driver (Electromagnetic launcher), possibility of frequent launching can be established.

\section{REFERENCES}

1. M. H. Ziraksaz, "How to Design, Build and Test Small Solid Propellant Rocket motor (Part one)" Science and Research Branch, Islamic Azad University, Tehran, Iran, 45th AIAA/ASME/SAE/ASEE Joint Propulsion Conference \& Exhibit 2 - 5 August 2009, Denver, Colorado.

2. Ashish Chandra, Capacitor Bank Designing for Power Factor Improvement, , ACTS India IJETAE,2014, 4, 8,

3. A brief history of U.S. Navy Torpedo Development - NUSC technical document 5436, 15'September, 1978.

4. Humble, Ronald. Gary N. Henry, and Wiley J. Larson. Space Propulsion Analysis and Design. New York, NY: McGraw-Hill, Inc., 1995.

5. Isakowitz, Steven J. International Reference Guide to Space Launch Systems. Washington, D.C.: American Institute of Aeronautics and Astronautics (AIAA), 1999.

6. Sellers, Jerry J.et. al., "Investigation into Cost- Effective Propulsion System Options for Small Satellites." Journal of 


\section{Experimental Examination of Scalable Under Water Launching Missile System}

Reducing Space Mission Cost. Vol. 1, No. 1, 1998.

7. Wertz, James R. and Wiley J. Larson. Space Mission Analysis and Design. Third edition. Dordrecht, Netherlands: Kluwer Academic Publishers, 1999.

8. D. Abhijeet singh, "Sugar Based Rocket Propulsion System-Making, Analysis \& Limitations", International Journal of Engineering Trends and Applications (IJETA) Volume 2 Issue 5,2015

9. Muad Al Khaldi, "The Rail Gun", EE 340-2 Electromagnetic students research project report 2008/2009(081)

10. Ashish Chandra1, "Capacitor Bank Designing for Power Factor Improvement", IJETAE, 2014, Vol. 4, no.8.

11. Gumbel, J. Aerodynamic influences on atmospheric in situ measurements from sounding rockets. J. Geophys. Res. Space Phys. 2001, 106, 10553-10563.

12. Guery, J.-F., Chang, I.-S., Shimada, T., Glick, M., Boury, D., Robert, E., Napier, J., Wardle, R., Pérut, C., Calabro M, "Solid propulsion for space applications: An updated roadmap". Acta Astronaut. 2010, 66, 201-219.

13. Sommerer, S.; Guevara, M.D.; Landis, M.A.; Rizzuto, J.M.; Sheppard, J.M.; Grant, C.J. System- of-Systems Engineering in Air and Missile Defense. Johns Hopkins APL Tech. Dig. 2012, 31, 5-20

14. Stein, G.H. Forty Years of Model Rocketry: A Safety Report; Publication of the National Association of Rocketry: Marion, IA, USA, 1997.

15. Johan Gallant, Eline Vanderbeke, Farid Alouahabi, and Markus Schneider," Design Considerations for an Electromagnetic Railgun to be Used Against Antiship missiles", IEEE Transactions on Plasma Science, Vol. 41, No. 10, 2013.

16. Ian R. McNab," Launch to space with an electromagnetic railgun". IEEE Transacts On Magnetism, Vol. 39, No. 1, January 2003.

17. Suvir Phulari, Swagat Bhingole, Nagnath Chavan, Vatan Meher, Anup Singh Chandrashekar,"Railgun",Dr. Babasaheb Ambedkar Technology University,2016.

18. Dwight S. Warnock, "Design and Optimization of a 600 KJ Rail gun powder supply", Naval Postgraduate School, Monterey, California, September 2003.

\section{AUTHORS PROFILE}

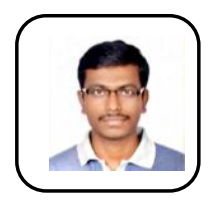

J. Sarathkumar Sebastin working as Assistant Professor in Aeronautical Engineering, Kalasalingam Academy of Research and Education. The author has published papers in the areas of Solid propellants, UAV and propulsion.

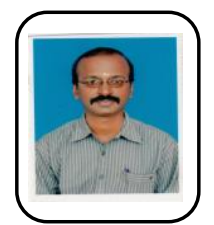

Dr. S. Jeyakumar working as Professor in Aeronautical Engineering, Kalasalingam Academy of Research and Education. The author has published papers in the areas of high-speed flow mixing and combustion, cavity flow, dual combustion ramjet engine. 